\title{
Utilization of brick waste as pozzolanic material in concrete mix
}

\author{
Raghda Resin $^{1}$, Abeer Alwared ${ }^{1}$, Suhair Al-Hubboubi ${ }^{2}$ \\ ${ }^{1}$ Environmental Department, College of Engineering, Baghdad University, Baghdad, Iraq \\ ${ }^{2}$ Building Research Directorate, Ministry of Construction and Housing, Baghdad, Iraq
}

\begin{abstract}
Recycling of construction and demolition waste and recycling of industrial by-products into building materials has an enormous potential. Brick waste can be treated by reusing for construction. Recently, the utilization of pozzolanic materials in cement and concrete have increased considerably due to their diverse benefits such as lesser use of cement, saving in production costs, improvement in the durability of concrete and so on. Ground bricks was added to concrete mix as partial replacement of cement at $(5,10,15) \%$ by weight. It was evaluated as a pozzolanic material in conjunction with high range water reducing admixture superplasticizer (HRWR)-The study confirmed that the use of $10 \%$ of ground brick improved compressive, flexure strength of concrete by about $(23.3 \%)$ and $(5.92 \%)$ respectively at 240 days as compared to reference concrete and decreased the depth of water penetration under pressure by about $43.75 \%$ at 150 days, also the water absorption decreased by about $2.52 \%$. The uses of $10 \%$ of grinding brick in conjunction with high range water reducing admixture reduced corrosion of steel reinforcement by about $18 \%$.
\end{abstract}

\section{Introduction}

Preservation of the environment and conservation of rapidly diminishing natural resources should be the essence of sustainable development. Continuous industrial development poses serious problems in construction and demolition waste disposal [1].Construction and demolition (C\&D) waste could be broken concrete, bricks from buildings, or broken pavement. Brick waste is not the major amount of waste in construction, but it contributes largely in demolition activities. These waste materials are directly dumped into the environment and it causes environmental pollution as well as scarcity of landfill .Thus, waste utilization has become an alternative solution to overcome the problem for disposal of waste instead of minimizing the brick waste produced, it can increase the strength and performance of concrete production. Further, it also helps in minimizing the land fill scarcity problem [2] .Concrete is one of the most widely used construction materials in the world. However, the production of Portland cement, an essential constituent of concrete, leads to the release of significant amount of $\mathrm{CO}_{2}$, a greenhouse gas (GHG). The production of one ton of Portland cement produces about one ton of $\mathrm{CO}_{2}$ and other GHGs. The environmental issues associated with GHGs, in addition to natural resources issues, will play a leading role in the sustainable development of the cement and concrete industry during this century [3]. Research studies revealed that pozzolanic materials significantly improve the properties of concrete [4][5][6].Material transport properties, especially permeability, affect the durability and integrity of a structure. High permeability, due to porosity or cracking, provides ingress for water and other corrosive agents. If such agents reach reinforcing bars within the structure, the bars corrode, thus compromising the ability of the structure to withstand loads, which eventually leads to structural failure. Therefore, there has been an interest in determining the permeability of pozzolanic material concrete compared with conventional concrete [7] The aim of this study focuses on the feasibility of using bricks of locally available construction waste for establishing economically-friendly and affordable green environment through evaluating its pozzolanic activity and checking the suitability as partial replacement of cement to produce high performance concrete. 


\section{Experimental work}

\subsection{Materials}

Cement: Ordinary Portland cement conforming to IQS No. 5/1984 was used in all types of concrete mixes in this work. Tables ( 1 and 2) represent the chemical and physical properties of the used cement respectively.

Fine aggregate: Natural sand of zone (1) conforming to IQS No.45/1984 was used as fine aggregate. The gradation of the used fine aggregate and its physical and chemical tests were shown in Tables (3 and 4).

Coarse aggregate: Crushed river gravel with $20 \mathrm{~mm}$ maximum size was used as coarse aggregate. Table (5) shows the properties of coarse aggregate which conforms to Iraqi standards No.45/1984.

High Range Water Reducing Admixture:

High range water reducing admixture (HRWR) superplasticizer, known as (PC2000) complies with ASTM C 494 type $\mathrm{N}$ was used. It decreases water/cement ratio to improve the mechanical property of concrete and durability. It was used in dosages between ( 0.5 to 1.5$)$ percent of the cement weight. The properties of this admixture are listed in Table (6).

Waste Brick Powder:

The waste bricks obtained from the garbage of a demolished building were grinded in Jet mills machine and then sieved to get the desired particle size $(100 \mu \mathrm{m}$, sieve No.150), Fig. (1). its chemical and physical properties are summarized in Tables (7) and (8)
All the materials used in this work were supplied by the Iraqi local market. The properties of cement, fine an respectively. X-ray diffraction, Fig. (2), shows that brick composed of quartz (being the main component), illite, albite, and hematite. However, the intensities of XRD patterns of bricks are different and suggest that the bricks were manufactured differently by using materials of high clay content. [8].

Steel Reinforcement:

For half-cell potential measurement, deformed steel bars of $12.5 \mathrm{~mm}$ diameter and $400 \mathrm{~mm}$ length were used to reinforce test specimens; the steel bars were cleaned thoroughly using steel brush for removing any rust deposits from their surfaces. Table (9) represents the physical properties of the steel bars.

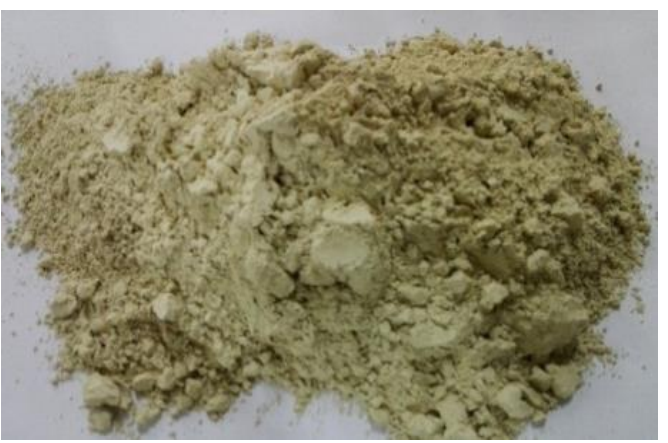

Fig. 1. Brick powder passing sieve (No. 150)

Table1. Chemical properties of cement

\begin{tabular}{|c|c|c|c|}
\hline $\begin{array}{l}\text { Compound } \\
\text { composition }\end{array}$ & Abbreviation & $\begin{array}{l}\text { Percent by } \\
\text { weight }\end{array}$ & $\begin{array}{c}\text { Limit of IQS } \\
\text { No.5/1984 }\end{array}$ \\
\hline Lime & $\mathrm{CaO}$ & 62.73 & - \\
\hline Silica & $\mathrm{SiO}_{2}$ & 20.41 & - \\
\hline Alumina & $\mathrm{Al}_{2} \mathrm{O}_{3}$ & 4.91 & - \\
\hline Iron oxide & $\mathrm{Fe}_{2} \mathrm{O}_{3}$ & 3.21 & - \\
\hline Magnesia & $\mathrm{MgO}$ & 2.6 & $\leq 2.85 \%$ \\
\hline Sulfate & $\mathrm{SO}_{3}$ & 2.8 & $\leq 5 \%$ \\
\hline Loss on ignition & L.O.I & 3.17 & $\leq 4 \%$ \\
\hline Insoluble residue & I.R & 1.05 & $\leq 1.5$ \\
\hline Lime saturation factor & L.S.F & 0.93 & $0.66-1.02$ \\
\hline \multicolumn{4}{|c|}{ Main compounds $\%$ by weight } \\
\hline \multicolumn{2}{|c|}{ Name of compounds } & Abbreviation & $\begin{array}{c}\text { Percent by } \\
\text { weight }\end{array}$ \\
\hline \multicolumn{2}{|c|}{ Tri calcium silicate } & $\mathrm{C}_{3} \mathrm{~S}$ & 49.57 \\
\hline \multicolumn{2}{|c|}{ Di calcium silicate } & $\mathrm{C}_{2} \mathrm{~S}$ & 21.36 \\
\hline \multicolumn{2}{|c|}{ Tri calcium aluminate } & $\mathrm{C}_{3} \mathrm{~A}$ & 7.58 \\
\hline
\end{tabular}


Table2. Physical properties of cement

\begin{tabular}{|c|c|c|}
\hline Physical properties & $\begin{array}{c}\text { Limits of } \\
\text { cement }\end{array}$ & $\begin{array}{c}\text { Limits of IQS } \\
\text { No. 5/1984 }\end{array}$ \\
\hline Fineness Blaine $\mathrm{m}^{2} / \mathrm{kg}$ & 359.7 & $\geq 230$ \\
\hline Initial setting time (h:min) & $1: 35$ & $\geq 00: 45$ \\
\hline Final setting time (h:min) & $4: 40$ & $\leq 10: 00$ \\
\hline $\begin{array}{c}\text { Compressive strength }(\mathrm{MPa}) \\
\text { 3 days }\end{array}$ & 28 & $\geq 15$ \\
7 days & 34 & $\geq 23$ \\
\hline
\end{tabular}

Table3. Gradation of fine aggregation

\begin{tabular}{|c|c|c|}
\hline $\begin{array}{c}\text { Sieve size } \\
(\mathrm{mm})\end{array}$ & $\begin{array}{c}\text { Percentage } \\
\text { passing \% }\end{array}$ & $\begin{array}{c}\text { Limit of IQS } \\
\text { No.45/1984 } \\
\text { zone (1) }\end{array}$ \\
\hline 10 & 100 & 100 \\
\hline 4.75 & 97 & $90-100$ \\
\hline 2.36 & 77.9 & $60-95$ \\
\hline 1.18 & 51.6 & $30-70$ \\
\hline 0.6 & 30.3 & $15-34$ \\
\hline 0.3 & 10.9 & $5-20$ \\
\hline 0.15 & 2 & $0-10$ \\
\hline
\end{tabular}

Table 4. Physical and chemical properties of fine

\begin{tabular}{|c|c|c|}
\hline Properties & Values & $\begin{array}{c}\text { Limits of IQS No.45- } \\
1984\end{array}$ \\
\hline Sulfite \% $\left(\mathrm{SO}_{3}\right)$ & 0.18 & $\leq 0.5 \%$ \\
\hline $\begin{array}{c}\text { Fineness } \\
\text { modulus }\end{array}$ & 3.3 & --- \\
\hline Absorption \% & 1.5 & ---- \\
\hline
\end{tabular}

Table5. Gradation for coarse aggregate

\begin{tabular}{|c|c|c|}
\hline $\begin{array}{c}\text { Sieve size } \\
(\mathrm{mm})\end{array}$ & $\begin{array}{c}\text { Percentage } \\
\text { passing \% }\end{array}$ & $\begin{array}{l}\text { Limit of Iraqi standards } \\
\text { No. (45/1984) }\end{array}$ \\
\hline 20 & 100 & 100 \\
\hline 10 & 23.5 & $0-25$ \\
\hline 5 & 1.15 & $0-10$ \\
\hline
\end{tabular}

Table 6. Properties of HRWR

\begin{tabular}{|c|c|}
\hline Chemical content & Poly-carboxylate based \\
\hline Color, appearance & Brown liquid \\
\hline PH & $0.5 \pm 6$ \\
\hline Density & $1.03 \pm 0.02 \mathrm{~g} / \mathrm{cm} 3$ \\
\hline Chloride content $(\%)$ & Without chloride ion \\
\hline
\end{tabular}


Table 7. Chemical Properties of waste brick powder

\begin{tabular}{|c|c|c|}
\hline $\begin{array}{c}\text { Oxide } \\
\text { composition }\end{array}$ & Oxide content $\%$ & $\begin{array}{c}\text { ASTM C618 } \\
\text { Class C limitation }\end{array}$ \\
\hline $\mathrm{SiO}_{2}$ & 39.35 & \multirow{2}{*}{ Min $50 \%$} \\
\hline $\mathrm{Al}_{2} \mathrm{O}_{3}$ & 17.77 & \\
\hline $\mathrm{Fe}_{2} \mathrm{O}_{3}$ & 2.40 & \\
\hline $\mathrm{SO}_{3}$ & 1.60 & \multirow{2}{*}{ Max. $5 \%$} \\
\hline $\mathrm{CaO}$ & 23.2 & \\
\hline $\mathrm{MgO}$ & 7.5 & \\
\hline L.O.I & 2.59 & \\
\hline Others & 5.5 & \\
\hline Total & 99.91 & \\
\hline
\end{tabular}

Table 8. Physical properties of brick waste

\begin{tabular}{|c|c|c|}
\hline $\begin{array}{c}\text { Physical } \\
\text { properties }\end{array}$ & Brick & $\begin{array}{c}\text { ASTM C618 Class C } \\
\text { Limitation }\end{array}$ \\
\hline $\begin{array}{c}\text { Fineness: } \\
\text { Amount retained } \\
\text { when wet-sieved } \\
\text { on } 45 \mu \mathrm{m} \text { (No. } \\
325 \text { ) sieve, } \%\end{array}$ & 20 & Max 34 \\
\hline Specific gravity & 2.98 & \\
\hline
\end{tabular}

Table 9. Physical properties of the steel deformed bars

\begin{tabular}{|c|c|c|}
\hline & Properties & $\begin{array}{c}\text { limits of the American } \\
\text { standard (ASTM A615) of } \\
\text { steel type (420) }\end{array}$ \\
\hline $\begin{array}{c}\text { Tensile strength } \\
\left(\mathrm{N} / \mathrm{mm}^{2}\right)\end{array}$ & 619.2278 & 620 Min. \\
\hline $\begin{array}{c}\text { Yield strength } \\
\left(\mathrm{N} / \mathrm{mm}^{2}\right)\end{array}$ & 542.064314 & 420 Min. \\
\hline Elongation $(\%)$ & 16.182573 & $9 \%$ for dia.12 Min. \\
\hline
\end{tabular}

\subsection{Concrete mix proportions}

Concrete mixture consists of $400 \mathrm{~kg} / \mathrm{m}^{3}$ cement, $750 \mathrm{~kg} / \mathrm{m}^{3}$ sand, $1035 \mathrm{~kg} / \mathrm{m}^{3}$ gravel, and a w/c was ranged within (0.41-0.51), 1.2\% HRWR by weight for reference concrete and $1.4 \%$ for brick -modified concrete and it was designed to achieve compressive strengths of 50 $\mathrm{MPa}$ at 28 days. The slump was kept within the range (80-90) $\mathrm{mm}$ as shown in Table (10).

According to a typical mixing procedure, a mixer of a 20 $\mathrm{kg}$ capacity was used to prepare the concrete mix: First, gravel and sand wee mixed together and followed by cement, initially mixed dry material for $1.5 \mathrm{~min}$; finally, the addition of HRWR and $30 \%$ of water together. After 1.5 min of mixing, the remaining water was added to the mixer. Then all batches were mixed for about $2 \mathrm{~min}$. The water was adjusted to maintain a slump within the range .To prevent fresh concrete from segregation. The mixing duration was kept as low as possible. For the testing, specimens of the hardened properties were prepared by direct pouring of concrete into molds with compaction by vibrating table. High performance concrete was mixed by a similar procedure to reference concrete except that the required quantity of brick powder was mixed with dry cement very well .Then mixed with other ingredients in the same manner as for reference concrete. 
Table 10. Concrete mix

\begin{tabular}{|c|c|c|c|c|c|c|c|}
\hline $\begin{array}{c}\text { Concrete } \\
\text { mix }\end{array}$ & $\begin{array}{c}\text { Cemen } \\
\mathrm{kg} / \mathrm{m}^{3}\end{array}$ & $\begin{array}{c}\text { Waste } \\
\text { added } \\
\mathrm{kg} / \mathrm{m} 3\end{array}$ & $\begin{array}{c}\text { ercentage } \\
\text { of waste } \\
\%\end{array}$ & $\begin{array}{c}\text { Fine } \\
\text { aggreg } \\
\text { ate } \\
\mathrm{kg} / \mathrm{m}^{3}\end{array}$ & $\begin{array}{c}\text { Coarse } \\
\text { aggrega } \\
\text { te } \\
\mathrm{kg} / \mathrm{m}^{3}\end{array}$ & w/c ratio & $\begin{array}{c}\text { HRWR } \\
\text { adm., } \%\end{array}$ \\
\hline R & 400 & 0 & 0 & 750 & 1035 & 0.41 & 1.2 \\
\hline B5 & 380 & 20 & 5 & 750 & 1035 & 0.51 & 1.4 \\
\hline B10 & 360 & 40 & 10 & 750 & 1035 & 0.47 & 1.4 \\
\hline B15 & 340 & 60 & 15 & 750 & 1035 & 0.48 & 1.4 \\
\hline
\end{tabular}

R: reference concrete Mix; B5, B10, B15: 5, 10, 15\%brick,

\subsection{Curing procedures}

Concrete casting was performed in two layers. Each layer was compacted by using a vibrating table until no air bubbles emerged from the surface of concrete and the concrete was adjusted to the top of the mold smoothly (ASTM C192-88). The specimens then were kept in the laboratory for about (24) hrs. The specimens were covered with nylon sheets to prevent evaporate on of water from the concrete. After that the specimens were remolded carefully, immersed in tap water in the curing basin at room temperature until the time of testing.

\subsection{Experimental program}

Tests for hardened concrete were; strength activity index (ASTM C311) [9], compressive strength B.S 1881: Part 116 [10], flexural strength (ASTM C293-79) [11], depth of water penetration under pressure (BS EN 123908:2009), absorption after immersion (ASTM C642-97) [12] and The electrochemical potential of the reinforcing steel was measured relative to a copper-copper sulfate electrode (CSE). The relationship between half-cell potential and corrosion of steel embedded in concrete are shown in Table (11) .The half -cell potential measurements are interpreted according to ASTM C 87699 [13]. The compressive strength test was done with 60 cubes at the ages of 7, 28, 90, 150 and 240 days. The flexural strength and absorption after immersion tests were done with 12 specimens for each test at the age of 150 and 240 days. The depth of water penetration under pressure was done with 6 cubes at the age of 150 day. The half-cell potential measurements was done with 6 specimens and monitoring the current at different period of time.
Table 11. Relationship between half - cell potential and corrosion of steel embedded in concrete (ASTM c 876-99)

\begin{tabular}{|l|l|}
\hline $\begin{array}{l}\text { Half-cell potential } \\
(\mathrm{mV})\end{array}$ & Interpretation \\
\hline$>-200$ & Low probability of corrosion \\
\hline-200 to -350 & Uncertain corrosion activity \\
\hline$<-350$ & high probability of corrosion \\
\hline
\end{tabular}

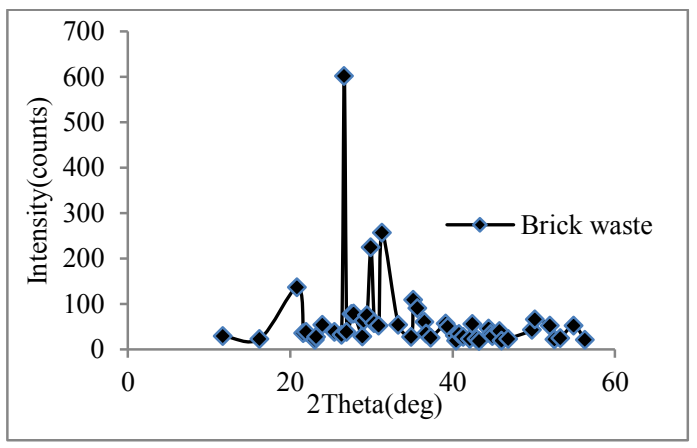

Fig. 2 X-Ray analysis for brick waste

\section{Results and discussion}

\subsection{Strength activity index (SAI)}

SAI is used to determine if pozzolana results are within the acceptable level of strength development when used with hydraulic cement in concrete. The results may not provide a direct correlation of how pozzolana will contribute to strength in concrete, due to conduct the test with mortar. The strength activity index (SAI) of waste brick powder was determined with and without HRWR and the obtained values are presented in Table (12). The SAI of brick powder was within the limits of ASTM C618 class C at 7 days and 28days with or without HRWR however using the superplasticizer provide good spread of brick powder through the mixture and reduce the water requirement which led to a significant increase in strength. The total percentage of $\mathrm{SiO}_{2}+\mathrm{Al}_{2} \mathrm{O}_{3}+\mathrm{Fe}_{2} \mathrm{O}_{3}$ of brick powder was $59.52 \%$ which was within the limits of ASTM C618 class C, 
(Min50\%), due to high fineness of the brick powder. It filled the voids between cement particles and the sand and contributing to greater than $112 \%$ strength activity index, which could have contributed by the pozzolanic reaction of brick powder with $\mathrm{Ca}(\mathrm{OH})_{2}$, producing $\mathrm{C}-\mathrm{S}$ $\mathrm{H}$ and increasing the strength.

Table 12. Strength activity index (SAI)

\begin{tabular}{|c|c|c|c|c|c|c|}
\hline & \multicolumn{2}{|c|}{ Water requirement } & \multicolumn{2}{|c|}{$\begin{array}{c}\text { Strength Activity Index at } 7 \\
\text { days, } \%\end{array}$} & \multicolumn{2}{|c|}{$\begin{array}{c}\text { Strength Activity Index at } 28 \\
\text { days, } \%\end{array}$} \\
\hline & $\begin{array}{l}\text { Without } \\
\text { HRWR }\end{array}$ & $\begin{array}{c}\text { With } 1 \% \\
\text { HRWR of } \\
\text { cementitious } \\
\text { materials }\end{array}$ & $\begin{array}{l}\text { Without } \\
\text { HRWR }\end{array}$ & $\begin{array}{l}\text { With } 1 \% \\
\text { HRWR of } \\
\text { cementitious } \\
\text { materials }\end{array}$ & $\begin{array}{l}\text { Without } \\
\text { HRWR }\end{array}$ & $\begin{array}{l}\text { With } 1 \% \\
\text { HRWR of } \\
\text { cementitious } \\
\text { materials }\end{array}$ \\
\hline Brick & 103 & 84 & 75 & 97 & 82 & 112 \\
\hline $\begin{array}{c}\text { ASTM } \\
\text { C618 } \\
\text { Class C } \\
\text { Limitation }\end{array}$ & \multicolumn{2}{|c|}{$\begin{array}{l}\text { Max } 105 \% \\
\text { of control }\end{array}$} & \multicolumn{2}{|c|}{ Min 75} & \multicolumn{2}{|c|}{ Min 75} \\
\hline
\end{tabular}

\subsection{Compressive strength}

The effect of different content $(0,5,10$ and 15\%) by weight of brick waste as a partial replacement of cement on the compressive strength of concrete at various ages (7, 28, 90,150 and 240) days is shown in Fig.(3). It can be seen from this figure that the compressive strength of reference concrete was improved by the replacement with brick waste to a percentage less than $10 \%$ by weight at all curing ages but it start to decline as cement percentage reached $15 \%$ by weight at all curing ages but it was still higher than that of the reference concrete. This may be attributed to pozzolanic reaction [14]. $\quad \mathrm{SiO}_{2}$ reacts chemically with alkalis in cement and form cementitious product that contributes to the strength development, due to very fine powder of brick waste, also brick waste may be effectively filling the voids and giving rise to dense concrete microstructure. The maximum increase in compressive waste was $23.3 \%$ for $10 \%$ replacement of cement at 240 days curing age.

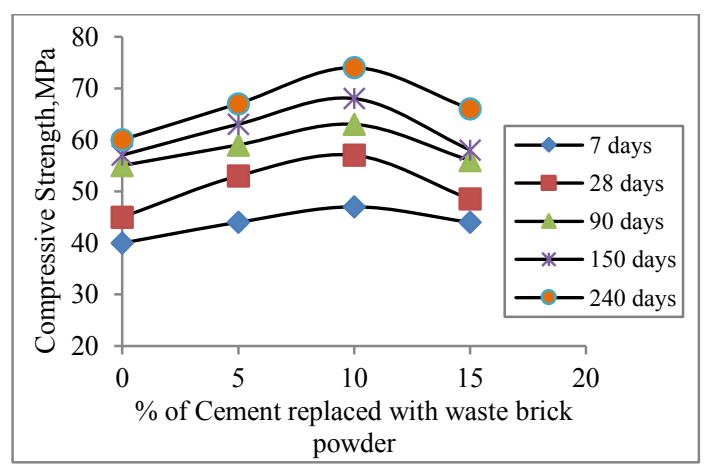

Fig. 3. Effect of various content of waste brick powder on compressive strength as compared with reference concrete

\subsection{Flexural strength}

The flexural strength test results for $10 \%$ by weight of brick waste are presented in Table (13). The flexural strength for reference concrete was improved by the replacement of $10 \%$ by weight brick waste as well as it tend to increase with increasing curing age from 150 to 240 days. This shows that significant pozzolanic reaction had taken place during this period of time. Similar observations were reported by [15][16].

Table 13. Flexural strength

\begin{tabular}{|c|c|c|}
\hline $\begin{array}{c}\text { Curing } \\
\text { ages(days) }\end{array}$ & $\begin{array}{c}\text { Reference } \\
\text { concrete }\end{array}$ & $\begin{array}{c}10 \% \text { brick - } \\
\text { concrete }\end{array}$ \\
\hline 150 & 3.88 & 4.38 \\
\hline 240 & 5.24 & 5.55 \\
\hline
\end{tabular}

\subsection{Premeability}

The results for water absorption test or the porosity test for $10 \%$ replacement brick waste-concrete and reference concrete at 150 and 240 day curing ages were plotted in Fig.(4), which indicated that the percentage water absorption for $10 \%$ brick waste- cement was less than that of reference concrete at all curing age, also it decreased with increasing curing ages from 150 to 240 days. The maximum reduction of water absorption was $13.87 \%$ as compared with reference concrete. This reduction in water absorption and water accessible porosity is attributed to the pozzolanic reaction of brick waste, which can refine the pore structures and decrease in the connectivity. The transport of water is governed by factors like pore connectivity and pore size distribution, 
other than water accessible porosity, indicating that pozzolanic reaction can refine the capillary pores for water transport due to more fineness property of particles than cement and the capacity of the pozzolanic towards fixing $\mathrm{Ca}(\mathrm{OH})_{2}$ generated during the reactions of hydration of cement.[17][18]These results are in agreement with the finding of [19]. The water penetration depth for $10 \%$ replacement brick waste-concrete and reference concrete are calculated for 150 days curing age and results present in Fig. (5), this figure shows that the depth of water penetration for brick - concrete was less than that for reference concrete. The incorporation of brick waste as replacement of cement content may improve the pore structure in the transition zone, and thereby reduce water permeability. The results are in agreement with those obtained by [20] who reported a reduction in the water depth penetration when using pozzlanic materials as cement replacement.

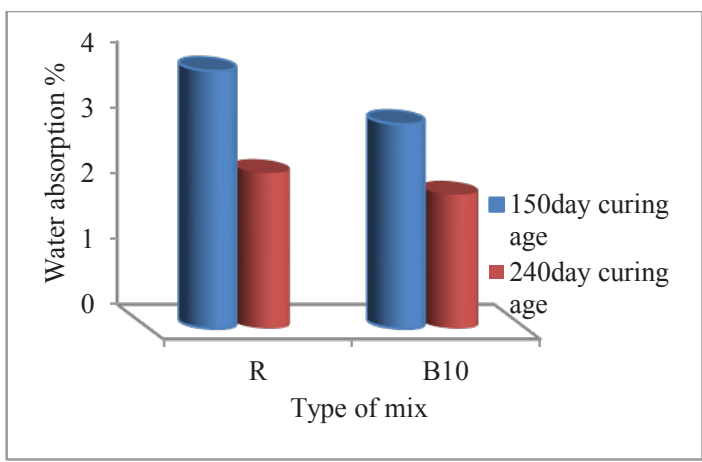

Fig. 4. Water absorption test

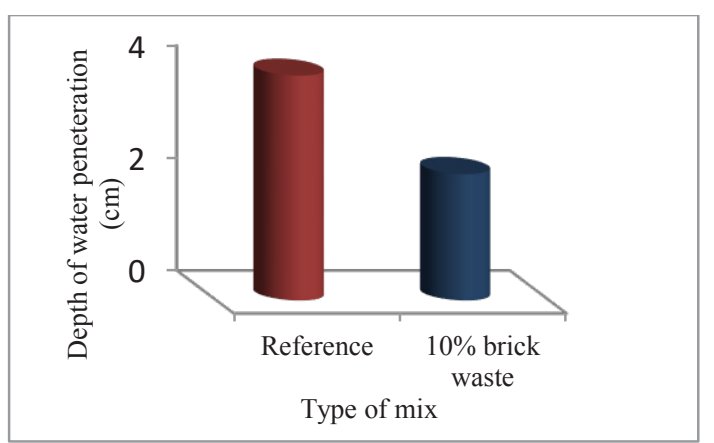

Fig. 5. Water penetration for the concrete mixes

\subsection{Half-cell potential}

The results of half-cell potentials of steel as referenced to a copper- copper sulphate electrode (CSE) for 10\% replacement brick - concrete and reference concrete embedded in 3.5\% $\mathrm{NaCl}$ solution were shown in Fig. (6).It is obvious that the potentials of steel in all types of concretes were shifted towards negative potential at the beginning of exposure period. The highly negative potential is not an indicative of high corrosion activity. This may be due to the higher moisture content of concrete after 28 days curing in tap water. The half-cell potential of steel increases with increasing moisture content of concrete [21]. At 150 days specimens of $10 \%$ by weight brick- concrete showed that the steel potential was $(-265 \mathrm{mV})$ which was lower than that of reference concrete $(-338 \mathrm{mV})$. This behaviour may be proposed on the basis of the better adsorptive capacity resulting in a barrier film difficult to break or penetrate by the corrosive chloride ions [22] after that it started to fluctuate and appeared to shift to more negative potential. At the end of 300 days of exposure the average potential in reference concrete reached $-356 \mathrm{mV}$, while the average potential of brick concrete reached $(-337 \mathrm{mV})$. It should be noted that all B10 concrete of steel potential was significantly below the threshold value stated by ASTM C876, Table 9. This pozzolanic reaction reduces the porosity and permeability of cement paste making it stronger and significantly more durable [23]. Use of superplasticizer in concrete lead to reduced water content and further to low permeability, thereby, reducing the penetrability of the aggressive ions.

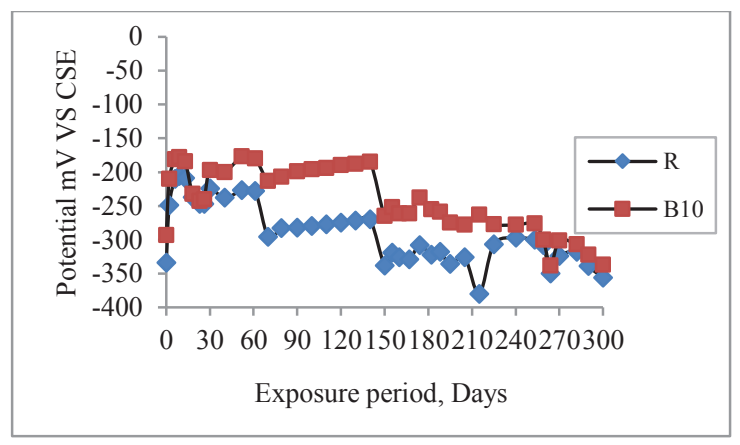

Fig. 6. Potential versus time behavior for $10 \%$ brick material concrete with reference concrete

\section{Conclusions}

This study concluded the performance of brick waste powder as supplementary cementitious materials to produce high performance concrete by using these materials in conjunction with high range water reducing admixture and minimizing the threat of these types of solid wastes for environmental protection. This study confirmed that the use of $10 \%$ of grinding brick improved strength of concrete and decreases the permeability of water under presser and reduced corrosion of steel reinforcement of about $18 \%$.

\section{References}

[1]T.B. Ilker, G.F.Nedim, 25,7(1995)

[2]B.V. Bahoria, D.K. Parbat and P.B., Naganaik J. of Envi. Res. And Deve. 7,4 (2013)

[3]T.R Naik ,. (2005)

[4] J. Bijen, Constr. \&Build. Mat., 10 (1996) 
[5], L. O. Ettu, N. N. Osadebe, and, M. S. W. Mbajiorgu, IJMER 3, 2 (2013).

[6]A A, Aliabdo, A M Abd-Elmoaty and H. H, Hassan, Alex. Eng J. 53 (2014)

[7]J.Rapoport, C.M., Aldea and S. P. Shah. Permeability of Cracked Steel Fiber-Reinforced (2002).

[8] T.Kavas, and A.Olgun, Ceramics 52,1 (2008),

[9] ASTM C311-02, pp. 9 (2002)

[10]BS 1881: Part 116- 1989, British Standards Institution, (2003).

[11] ASTM C293-79, 04, pp.162-163 (1979).

[12] ASTM C642-97, pp.1-2.1997.

[13]ASTM C876-99, p. 6. (2013).

[14] A. Heidari, and B.Hasanpour, Asian J. of Civil Engineering 14, 5 (2013)
[15] S Shruthi., S, Chandrakala and G. Narayana, IJRET: Inter. J. of Res. in Eng. and Tech. 4, (2015)

[16] T.Subramani, and S.B., Ram, IOSRJEN 05,05 ( 2015).

[17] V.M Malhotra and P.K. Mehta, London.

[18] S. Ghosal and S., Moulik, Int. J. of Eng.Res.4,9, (2015)

[19] D. Hongjian, H.J., Gao, and W. Li, ACMSM23 I, pp. 267-272. (2014).

[20]B., Menadi, S.Kenai, J. Khatiband, A. Al-Mokhtar, Con. \& Build. Mat. 23, pp 625-633,(2009)

[21] B.B. Hope and A.K., IP, 15, 3, pp.525-534. (1985).

[22]A.Phanasgaonkar, B.Cherry, and M., Forsyth, pp.6. (1997)

[23] R.Lewis, L., Sear, P. Wainwright, and R., Ryle, chapter3, pp. 66, (2003) 